\title{
ENTRE BONS E MAUS SELVAGENS A REPRESENTAÇÃO DO ÍNDIO NO CARNAVAL BRASILEIRO
}

\author{
Leonardo Augusto Bora (UFRJ)
}

O estudo enfoca, em cotejo com importantes obras da literatura brasileira, a complexa figura do "índio de cordão", representação carnavalesca de um "mau selvagem", que, nos cordões da virada do século XIX para o XX, no Rio de Janeiro, gerou bastante polêmica - e foi parar nas delegacias.

ÍNDIOS; CORDÕES; CARNAVAL; LITERATURA.

BORA, Leonardo Augusto. Entre bons e maus selvagens: a representação do índio no carnaval brasileiro. Textos escolhidos de cultura e arte populares, Rio de Janeiro, v.10, n.2, p. 109-126, nov. 2013. 


\section{BETWEEN GOOD AND EVIL SAVAGES}

THE REPRESENTATION OF THE INDIAN IN BRAZILIAN CARNIVAL

Leonardo Augusto Bora (UFRJ)

The study focuses on comparing - with important works of Brazilian literature - the complex figure of the "indio de cordão", a carnivalesque representation of a "bad savage", which, in the carnival groups of the turn of the 19 to the 20 century in Rio de Janeiro, generated considerable controversy - and ended up in police stations.

INDIANS; CORDÕES; CARNIVAL; LITERATURE.

BORA, Leonardo Augusto. Entre bons e maus selvagens: a representação do índio no carnaval brasileiro. Textos escolhidos de cultura e arte populares, Rio de Janeiro, v.10, n.2, p. 109-126, nov. 2013. 
Sou índio, sou forte, sou filho da sorte,

sou natural;

Sou guerreiro, sou a luz da liberdade,

Carnaval! ${ }^{1}$

E deu Tupi or not Tupi -

eis a visão do artista.

Nessa nação tupiniquim,

índio virou um anarquista! ${ }^{2}$

\section{O ÍNDIO NO CARNAVAL CARIOCA DO SÉCULO XIX: ENTRE BARBAS, LETRAS E TACAPES}

Um ponto comum às dezenas de manifestações carnavalescas que tomam de assalto os bairros da cidade do Rio de Janeiro nos dias (des)governados por Momo é o apreço pela fantasia, tradição que já no século XIX movimentava a economia e estimulava a imaginação dos brincantes. Pode-se dizer que a fantasia carnavalesca é a responsável pela instauração de um jogo duplo: entre identidade e alteridade e entre real e imaginário (FERREIRA, 1999, p. 98). No Brasil, a ascensão dos bailes de fantasiados, em meados do século XIX, é o fato responsável pela popularização do uso de trajes diferentes dos usuais durante os festejos que antecedem a Quaresma; até então, o carnaval era basicamente o entrudo, brincadeira um tanto violenta em que as pessoas usavam roupas sem maiores ornamentos: o povo brincava em sendo povo.

É na segunda metade do século XIX que as fantasias de índios ganham destaque nas folias de rua da cidade, conforme comenta Eneida de Moraes (1958, p. 97):

Nesse ano de 88 desfilou a Sociedade Carnavalesca Triunfo dos Cucumbis, o primeiro cordão organizado na cidade. Eram negros fantasiados de índios, tocando instrumentos primitivos. No centro levavam uma rainha com um grande manto segurado por dois mascarados, "dois figurões", políticos, possivelmente. Negros fantasiados de índios executando músicas e danças de africanos.

Maria Clementina Pereira Cunha (2001, p. 42) igualmente relata a ação dos negros fantasiados de índios, explicando o fio condutor da apresentação dos cucumbis:

A história contada pelos cucumbis representa um cortejo de príncipes, princesas, feiticeiros, embaixadores de outras nações africanas e o povo, levando para o rei do Congo seu filho recém-circun- 
Figura 1: Ilustração de Raul Pederneiras representando um índio de cordão, publicada no Jornal do Brasil de 14 de fevereiro de 1926 Fonte: Ferreira, 2004, p. 292

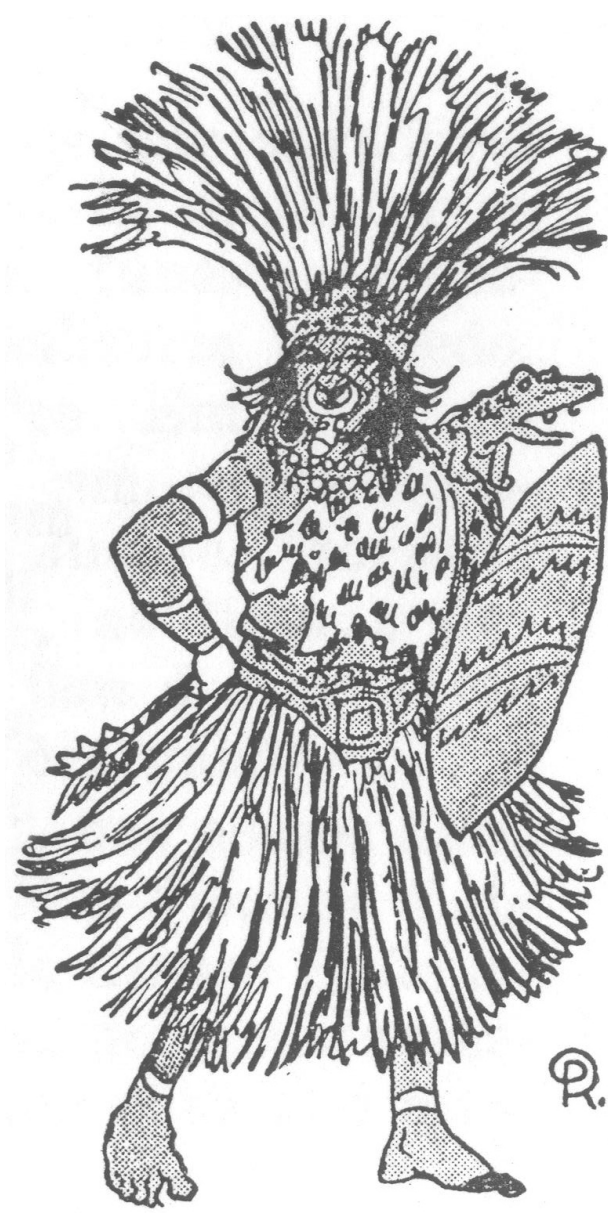

cidado. A morte do príncipe, atacado por tribo inimiga que se veste de penas, como os índios do Brasil, dá origem a uma série de peripécias, encerradas pela ressurreição do jovem por intermédio da mágica do feiticeiro. Além das saudações em português, o enredo fecha-se com louvações a São Benedito e à Virgem Maria, novamente cantadas no idioma dos brancos ao ritmo de ganzás, agogôs, xerequês, tamborins, chocalhos, marimbas e adufes - ao passo que todo o resto permanecia na língua africana. As fantasias envergadas pelos participantes do cucumbi eram também bastante características: para os índios, círculos de penas nos joelhos, cintura, braços e pulsos; cocares de plumas com palas vermelhas, colares de miçangas, corais e dentes.

Outra descrição do visual desses índios carnavalescos foi feita pelo historiador Luiz Edmundo (apud CUNHA, 2001, p. 177): usavam "vastos cocares de penas longas e coloridas, emoldurando rostos cor de canela, pintados a urucum, brincos de metal e colares de vidrilho; na boca sempre traziam um apito de bar- 


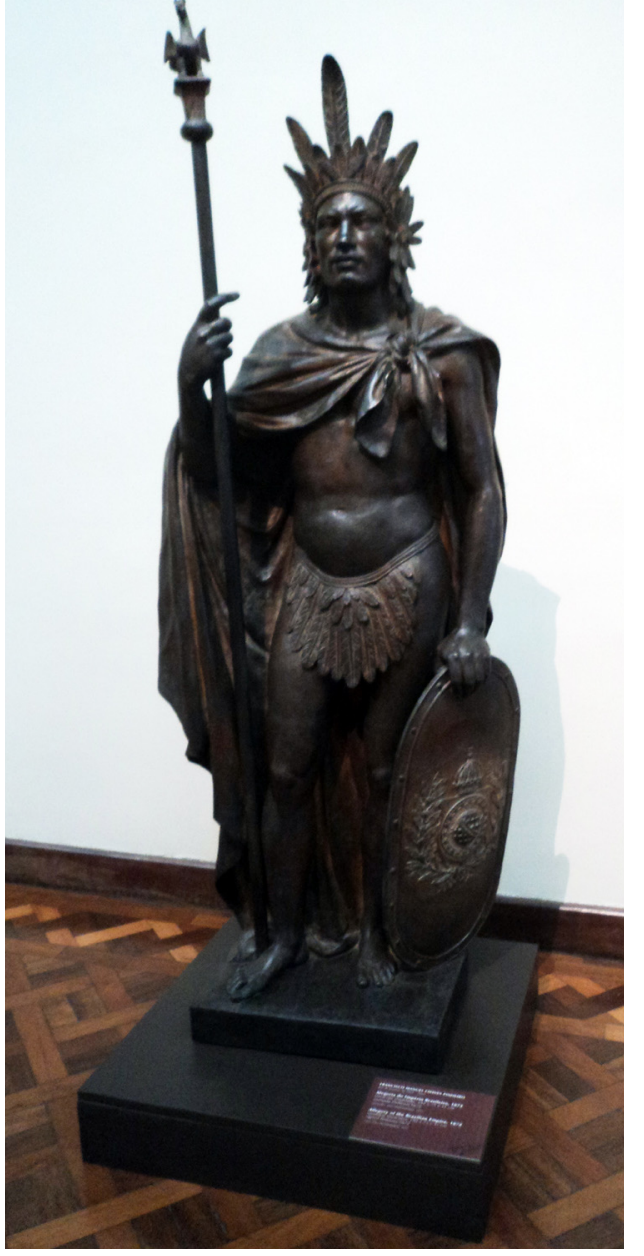

Figura 2: Alegoria do Império Brasileiro (Francisco Manuel Chaves Pinheiro, 1872), escultura de guerreiro indígena cujo escudo exibe as armas do Império, sintetizando a profunda ligação que havia entre o governo dos imperadores e a figura do índio; a obra está exposta no Museu Nacional de Belas Artes, no Rio de Janeiro; foto do autor

ro, por onde silvam, aos pulos; traziam atravessado nas costas um lagarto seco, uma serpente ou uma pele dura de jacaré" (Figura 1).

As fantasias de silvícolas são uma constante nas manifestações carnavalescas não apenas do Rio de Janeiro, mas do Brasil (vide os caboclinhos do Nordeste, por exemplo) e do mundo (vide as fantasias de "homens selvagens", presentes nos festejos carnavalescos de cidades da França, Suíça e Hungria (FERREIRA, 1999, p. 101) ou as manifestações carnavalescas não oficiais e negras de Nova Orleans, nos Estados Unidos, que não são comandadas por reis, mas por caciques, os black indians (GÓES, 2009). A existência dessas fantasias de índios nos carnavais populares do Brasil pode ser entendida como algo decorrente do fato de que os personagens carnavalescos são figuras periféricas da sociedade brasileira (DAMATTA, 1997, p. 62). ${ }^{3}$ É possível dizer, ainda, que as fantasias de selvagens, bem como as de "sujo" e de clóvis, ${ }^{4}$ surgiram numa delicada intercessão entre o meio popular e as fantasias "tradicionais", no intercâmbio entre os fluidos conceitos de popular e erudito (FERREIRA, 1999, p. 101). O índio, especificamente, ganha os festejos ao final de uma época em que figurara de maneira distinta no "mundo 
erudito" das orquestras e páginas literárias - sem esquecer das menções ao universo indígena e à natureza tropical, com abacaxis, aves, palmeiras entre outros elementos, feitas graficamente em telas, partituras, cartazes e objetos do período. A figura do índio, que tanto instigou o imaginário europeu à época das grandes navegações, no final do Renascimento (o "índio de tocheiro de Catarina de Médicis"5), no Brasil, foi, portanto, bastante difundida durante o Império (FERREIRA, 2004, p. 291-293).

A associação entre o índio e o governo dos imperadores não é descabida, uma vez que o nacionalismo estimulado após a independência, em 1822, propiciou a valorização dos cocares emplumados. ${ }^{6} \mathrm{Na}$ ficção romântica, os nativos das florestas eram a personificação da vontade de "fantasiar" uma nação de história curta, maquiando a mestiçagem com tintas heroicas (CANDIDO, 1959, p. 223). Tais índios estavam inseridos, portanto, no ideal nacionalista de descobrir as "raízes do Brasil", uma "utopia selvagem" retrospectiva disposta a dar "traços autóctones"7 à civilização brasileira. No plano político, Pedro II valeu-se do índio com o objetivo de associar a imagem do Império brasileiro à da natureza maraviIhosa, mãe de um povo cujo brado é retumbante (Figura 2). 0 indígena é alçado ao posto de símbolo nacional, como aponta, com riqueza de detalhes, a historiadora Lilia Moritz Schwarcz (1999, p. 204-205) em sua obra As barbas do imperador: D. Pedro II, um monarca nos trópicos"; nela, ao retratar as particularidades do Segundo Reinado, esclarece:

Sabia-se muito pouco a respeito dos indígenas, mas na literatura ferviam os romances épicos que traziam chefes indígenas heroicos, amores silvestres com a floresta virgem como paisagem. Os antigos dicionários de nossas línguas nativas feitos pelos jesuítas passaram a ser estimados, pois neles se escolhiam termos indígenas que poderiam ser entremeados às estrofes dos novos poemas. $\mathrm{O}$ próprio imperador, inspirado por essa voga, além de propor a criação de gramáticas e dicionários, começa a estudar o tupi e o guarani, que lhe seriam úteis durante os litígios com o Paraguai, na década de 60, e mesmo para que ganhasse uma espécie de liderança do movimento romântico. Cunhava-se então a representação do sábio mecenas.

Schwarcz afirma que a literatura cedeu espaço ao discurso oficial e transformou o índio em modelo de nobreza, ${ }^{8}$ ainda que, na realidade, trágica e ironicamente ele, o indígena, tenha sido uma grande vítima do processo colonizador que levou ao Império - e continuou a ser vitimado pela pena governamental, durante o reinado de Pedro II. ${ }^{9}$ 


\section{OS BONS E OS MAUS SELVAGENS: ENTRE RUAS E BIBLIOTECAS}

A vontade de retratar o indígena como um ser dotado de valores elevados ocasionou a condenação dos selvagens antropófagos, tidos como a expressão máxima da barbárie, nas páginas da literatura romântica indianista. Tanto Gonçalves Dias como José de Alencar desenharam os Aimoré como nativos ferozes, vis, sem qualquer indício de civilização. Nas páginas de Alencar (2006, p. 195), a descrição dos Aimoré, no capítulo de $O$ Guarani intitulado "Os selvagens", é marcada pela truculência:

Homens quase nus, de estatura gigantesca e aspecto feroz; cobertos de peles de animais e penas amarelas e escarlates, armados de grossas clavas e arcos enormes, avançavam soltando gritos medonhos.

A inúbia retroava; o som dos instrumentos de guerra misturado com os brados e alaridos formavam um concerto horrível, harmonia sinistra que revelava os instintos dessa horda selvagem reduzida à brutalidade das feras.

Nota-se, no excerto da obra, um sofisticado jogo de contrastes utilizado para endossar a ideia de que tais índios eram bárbaros e não expressavam os valores cortesãos. Alencar menciona "concerto horrível", estabelecendo uma oposição entre os gritos dos selvagens e a sutileza dos acordes de uma orquestra sinfônica, símbolo máximo do mundo erudito. Além disso, usa a expressão "harmonia sinistra" e compara os homens aos animais ferozes, visão que nada lembra a delicadeza de Iracema ou a hombridade valorosa de Peri, cuja descrição foi assim elaborada:

Sobre a alvura diáfana do algodão, a sua pele, cor de cobre, briIhava com reflexos dourados; os cabelos pretos cortados rentes, a tez lisa, os olhos grandes com os cantos exteriores erguidos para a fronte; a pupila negra, móbil, cintilante; a boca forte mas bem modelada e guarnecida de dentes alvos, davam ao rosto pouco oval a beleza inculta da graça, da força e da inteligência (ALENCAR, 1996, p. 28).

Se nas páginas literárias os índios "bárbaros" figuravam como coadjuvantes, posto que o protagonismo era dos índios cavalheirescos, alegórico modelo de lealdade que atendia aos interesses do trono, nas ruas do carnaval o estereótipo do selvagem animalizado roubaria a cena. $O$ índio dos cordões não viveria amores elevados, com aroma de baunilha, tampouco representaria os ideais românticos do Império, esfacelados em 1889: faria algazarra com o rosto pintado e empunharia tacapes nos cortejos negros. ${ }^{10}$ 
A fantasia do "índio de cordão" é, em sua configuração plástica, bastante peculiar. Na visão de Ferreira (2004, p. 291), "ao contrário de representar um índio brasileiro, (...) mais parece saída da imaginação de algum estrangeiro. A curiosa 'coroa' circular e o saiote, ambos feitos de penas, pouco têm a ver com o habitante original do Brasil. $O$ fato se explica através da visão que o europeu tinha do nosso índio". Trata-se, portanto, de outra idealização; se o romantismo literário pintou nossos indígenas com traços de donzelas e cavaleiros medievais, as vestes dos índios dos cordões são fruto da mistura de referências visuais dos índios americanos, o que resultou em uma figura genérica, síntese das diferentes culturas das Américas (p. 291). Havia, também, elementos da indumentária tribal africana, como escudos e máscaras - sobreposição de referências, explicitando a miscigenação.

Os brincantes dos cordões, aos poucos, passaram a ser mal vistos pela imprensa. Já não eram julgados pitorescos tão somente, mas incivilizados, rudes, violentos e potencialmente perigosos, a exemplo dos Aimoré literários. São esses personagens brutalizados que João do Rio (2008, p. 142) descreve em sua crônica "Cordões", de 1906:

Na turba compacta o alarma correu. O cordão vinha assustador. À frente, um grupo desenfreado de quatro ou cinco caboclos adolescentes com os sapatos desfeitos e grandes arcos pontudos corria abrindo as bocas em berros roucos. Depois um negralhão todo de penas, com a face lustrosa como piche, a gotejar suor, estendia o braço musculoso e nu sustentando o tacape de ferro. Em seguida gargolejava o grupo vestido de vermelho e amarelo com lantejoulas d'oiro a chispar no dorso das casacas e das grandes cabeleiras de coches, que se confundiam com a epiderme num empastamento nauseabundo. Ladeando o bolo, homens em tamancos ou de pés nus iam por ali, tropeçando, erguendo archotes, carregando serpentes vivas sem os dentes, lagartos enfeitados, jabutis aterradores com grandes gritos roufenhos.

Entre escudos, lanças e tacapes, aos olhos da elite, os cordões foram colocados em posição oposta à das civilizadas grandes sociedades. Não bastasse isso, a República recém-nascida pretendia enterrar os ideais do Império, refutando o apreço pelo nativismo e vendo na alva "pureza" dos imigrantes a solução racista para as mazelas do Brasil, supostamente geradas pela mistura carnal de brancos, índios e negros. É o que explica Maria Clementina Pereira Cunha (2001, p. 176):

Às vésperas da abolição, uma tônica quase decepcionada marcava os comentários da imprensa sobre os cucumbis e sobre a presença dos negros no carnaval, com suas formas tradicionais de apresen- 


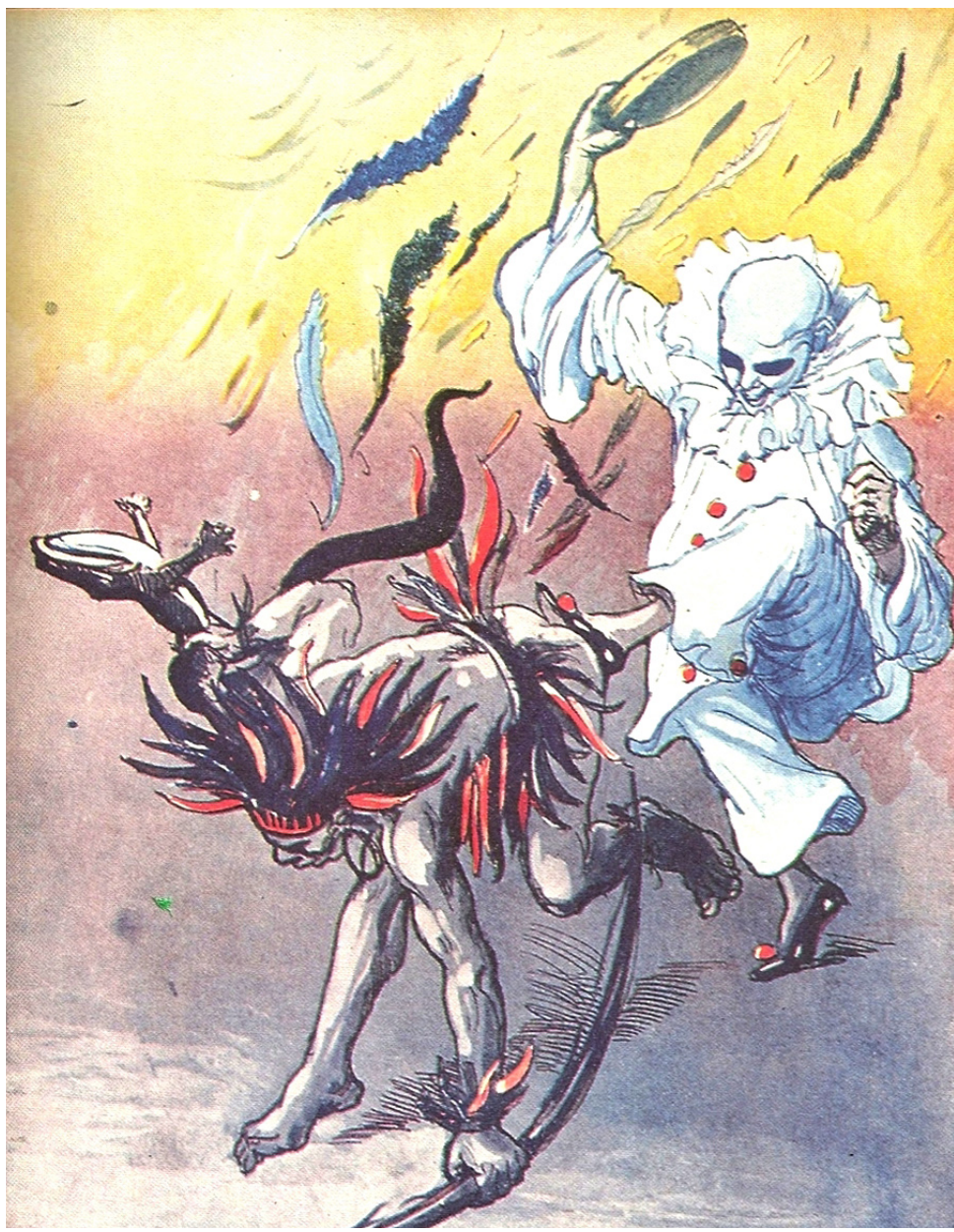

Figura 3:

Charge

publicada

na revis-

ta Careta

de 20 de

fevereiro

de 1909

Fonte:

Cunha, 2001, p. 388

tar-se na festa. Seguiu-se o discurso francamente racista da década de 1890, que desenhava os "africanismos" como uma ameaça ao próprio futuro do país. No século XX os cucumbis, alvos dessas críticas e desse temeroso olhar branco, haviam sumido das ruas, na forma como foram vistos no século anterior.

Começava o processo de esterilização da festa.

\section{A "LIMPEZA" DO CARNAVAL E A EXPULSÃO DO ÍNDIO: FOLIA À FRANCESA}

No início do século XX, a figura do índio estava intimamente associada ao carnaval mais popular e "selvagem" que precisava ser "chutado" para fora da folia (Figura 3). É o que se vê em charge de 1909, em que um pierrô branco, símbo- 
lo da europeização da festa, dá um pontapé violento no traseiro de um silvícola e o sorriso estampado no rosto do agente evidencia a felicidade com que a atitude é tomada. Penas voam, aos pedaços, num cenário de destruição; o "selvagem" tomba em tons acinzentados, sujos, ligados ao esquecimento.

Mais do que reflexo do apagamento simbólico dos apreços nacionalistas do Império, o desejo de expulsão foi decorrente do processo de "limpeza" pelo qual passou o carnaval carioca, em tempos de bota-abaixo. Ferreira (2004, p. 249) complementa as ideias de Cunha e explica essa espinhosa questão de maneira precisa:

Após a proclamação da República, o Brasil percebia a necessidade de se manter a unidade nacional, essencial para a legitimação do novo sistema de governo. O país precisava definir sua nacionalidade. E a pergunta sobre o que seria a verdadeira "essência da brasilidade" tornava-se de crucial importância para que o antigo símbolo da coroa pudesse ser substituído pela ideia de nação. Essa questão começara a ser discutida já na década de 1880, quando uma primeira geração de intelectuais nacionalistas abordaria o tema. No final do século XIX, a intelectualidade havia chegado à conclusão de que a grande responsável pelo atraso brasileiro em relação às nações mais desenvolvidas era a mestiçagem que existia no país. A preocupação com a necessidade que a nação tinha de superar esse atraso fazia com que muitos chegassem a afirmar que, se o povo brasileiro continuasse a se misturar, o Brasil iria se extinguir em alguns anos. Para eles a modernidade significava um Brasil europeizado e somente a imigração poderia "limpar" os efeitos perniciosos da miscigenação.

O Rio, "embranquecido", civilizava-se. A festa, igualmente, precisava de bons modos - e a repressão policial foi uma das formas de controlar a bagunça. Valendo-se da apregoada imagem de vandalismo associada aos cordões (e aos cucumbis, principalmente), a polícia buscava novas formas de controlar os foliões de saiotes e cocares. A burocracia estatal, por meio do seu braço armado, interferia nas brincadeiras, a ponto de, em 1904, a imprensa noticiar "que o cordão que não exibisse licença, quando solicitada por uma autoridade policial, seria levado com todos os seus componentes (...) para a polícia central (...)" (CUNHA, 2001, p. 196).

Enquanto isso, o corso, os ranchos e as grandes sociedades prosperavam a olhos vistos. Em 1908, a Avenida Central, com apenas quatro anos, observava a multidão de homens com chapéus de palhinha e mulheres elegantes que se aglomeravam para ver os desfiles dos Fenianos, Democráticos e Tenentes do Diabo. 
As janelas dos prédios da avenida eram ofertadas aos endinheirados, arquibancadas e palanques começavam a ser erguidos, decorações ainda singelas coloriam as ruas de inspiração francesa - culminando a prática na primeira decoração de rua oficial, feita por Luiz Peixoto, em 1928 (FERREIRA, 2004, p. 408). O carnaval de Nice era o parâmetro a ser seguido. Para isso, o governo passaria a investir maciçamente na festa, visando ao lucro; estava decidido a usar a imagem do carnaval como símbolo de um novo Brasil, republicano e civilizado, pronto para receber turistas de primeira classe. Nas palavras de Felipe Ferreira:

No final dos anos 20, o Carnaval do Rio de Janeiro já era visto como a grande festa nacional e sentia-se forte o suficiente para procurar ganhar o mundo. A separação cada vez mais precisa entre as diferentes formas de brincadeiras carnavalescas populares fazia com que a folia carioca se tornasse cada vez mais fácil de ser compreendida pela burguesia nacional. A "confusão" que reinara na virada do século estava em vias de ser totalmente substituída pelas novas categorias do carnaval de rua. Corso, Grandes Sociedades, ranchos, blocos e cordões formavam uma espécie de escala "decrescente" da folia, começando pela mais elegante e terminando na mais popular. Por trás desse tipo de classificação, havia uma ideologia que procurava expressar na festa carnavalesca todo o arco social brasileiro (FERREIRA, 2004, p. 310).

Eis que surge 1932, um ano de inflexão. ${ }^{11}$ O prefeito Pedro Ernesto decidiu associar a prefeitura ao Touring Club; juntos, organizariam o carnaval do Rio. $\mathrm{O}$ Touring Club impôs, em definitivo, caráter internacionalista à festa, criando uma "Comissão Executiva dos Festejos". Surgia, a partir disso, um "programa oficial" do carnaval carioca, no qual figuravam, entre outras atividades, os desfiles de blocos, corsos e grandes sociedades. Tratava-se, bem se vê, de uma organização rígida, uma grade com datas e horários preestabelecidos. E foi um sucesso, ao menos no meio da imprensa, que não poupou elogios ao prefeito. ${ }^{12}$

Nesse contexto de cifras e borbulhas de champanha, quando também tinha início a luxuosa tradição dos bailes do Municipal e o concurso das escolas de samba, na Praça Onze, os índios começariam a reaparecer, travestidos, transformados.

\section{A FOLIA ANTROPOFAGIZA-SE: NOVOS ÍNDIOS, NOVOS TEMPOS}

A temática indígena esteve em alta, nos círculos da intelectualidade tupiniquim, nos anos 20 e 30. Macunaíma, de Mário de Andrade, e Cobra Norato, de Raul Bopp, são apenas dois exemplos literários que comprovam o interesse 
que as lendas indígenas despertavam nos escritores da chamada Primeira Geração Modernista. Em 1923, Oswald de Andrade, aríete do Modernismo brasileiro, defendeu, em Paris, a "presença sugestiva do tambor negro e do canto do índio" nas festas do nosso carnaval (FERREIRA, 2004, p. 257). Nas artes plásticas, a pintura de Tarsila do Amaral ilustrou a antropofagia oswaldiana, que demarcava, com a morte do bispo Sardinha devorado pelos Caeté, o início da Terra Brasilis. Na arquitetura, o movimento Art Déco coloriu-se de verde e amarelo e apresentou inusitados traços marajoaras, com muiraquitãs e grafismos indígenas estilizados, em edifícios como o Itahy e o Itaoca, em Copacabana. A música de Villa Lobos, por sua vez, com incursões pelo Amazonas, sintetiza a mitologia da floresta tropical nas partituras dos anos 20.

Nesse contexto nativista, perdia força o entendimento de que a folia carioca deveria apenas imitar os festejos europeus e crescia o interesse pela diversidade do Brasil, fomentando a necessidade de novos símbolos, diferentes daqueles observados nas folias do século XIX:

A visão modernista vai incorporar ao sentido de desafogo do cotidiano a ideia do Carnaval como uma forma de resistência "antropofágica" do povo brasileiro às imposições externas. Uma espécie de liquidificador capaz de transformar tudo em loucura carnavalesca (...) A partir dessa constatação, estava pavimentado o caminho para que a festa carnavalesca do Rio de Janeiro se tornasse a maior expressão da índole e da 'alma' brasileiras. Uma festa múltipla, que sintetizaria um país plural, produto da reunião de muitas diferenças (...) O carnaval passava a representar a síntese do Brasil (FERREIRA, 2004, p. 325).

No campo das serpentinas, porém, não foi o índio o símbolo escolhido para os novos tempos. Entravam em cena, para continuar sob os holofotes, até hoje icônicos, malandros e baianas. A roupa de malandro não era exatamente uma novidade: muitos brincantes trajavam paletós e chapéus de palhinha já no século XIX, por influência francesa. Quando os intelectuais descobriram o samba, nos anos 20, ganhou outra conotação a vestimenta típica dos negros sambistas dos morros, composta por sapato bicolor, calça branca, chapéu e camisa listrada. Juntamente com isso, a vestimenta de baiana giraria o mundo. Saias rodadas, rendas, torços e tabuleiros com quitutes eram comuns no Rio de Janeiro imperial. ${ }^{13}$ Nos primeiros anos da década de 1930, "a figura teria seus traços fixados definitivamente no imaginário carnavalesco nacional" (FERREIRA, 2004, p. 259). ${ }^{14}$

Esse conjunto de símbolos encontraria nas nascentes escolas de samba um terreno fértil, tanto que no segundo ano de concurso oficial muitas postulantes ao título apresentaram enredos que tinham a mítica Bahia como vedete 
principal. Na bicampeã Mangueira, "Uma segunda-feira do Bonfim, na Ribeira"; na Azul e Branco do Salgueiro, "Uma noite na Bahia"; na União do Uruguai, "Na Bahia". ${ }^{15}$ Afora essas referências, os desfiles dos anos 30 elegeram o próprio samba como tema principal, demarcando o território e solidificando o ritmo, ao som dos tamborins.

Curioso é o fato de que as escolas demorariam a assimilar em definitivo os temas africanos e indígenas. A fantasia de índio, à base de penas de pato ou de plumas de espanador (daí a denominação "índio de espanador", comum no carnaval), é barata, assim como a roupa de africano, à base de tecidos grosseiros e palha. Não havia, porém, o compromisso com o desenvolvimento de um enredo de temática indígena. A chamada "revolução salgueirense", cujos expoentes foram o professor da Escola de Belas Artes Fernando Pamplona acompanhado de Arlindo Rodrigues, na transição dos anos 50/60, é considerada a responsável pela internalização da africanidade nos desfiles das escolas de samba, que, até então, preferiam temas governistas e fantasias de veludo e bordados. Na esteira do negro, o índio passaria, nas décadas de 1960 e 1970, a aparecer mais vezes, inserido em enredos como "Aquarela Brasileira", do Império Serrano, em 1964, "Lendas e Mistérios da Amazônia", da Portela, em 1970, e "Macunaíma, herói da nossa gente", também da Portela, em 1975. Bons representantes dos enredos de temática integralmente indígena são "Como era verde o meu Xingu", de Fernando Pinto, para a Mocidade Independente de Padre Miguel, em 1983; "Raízes", de Max Lopes, para a Unidos de Vila Isabel, em 1984; "O dono da terra", de Oswaldo Jardim, para a Unidos da Tijuca, em 1999, e "Ykamiabas", de Fábio Ricardo, para a Acadêmicos da Rocinha, em 2010. "Todo dia é dia de índio", de Chico Spinosa, para a União da Ilha, em 1995, é um enredo síntese dos desdobramentos de 1922. "Tupinicópolis", carnaval de Fernando Pinto para a Mocidade Independente, em 1987, é um dos enredos mais originais que a Passarela já viu; trata-se de inventiva revisão histórica que imagina uma cidade brasileira moderna, pós-industrial, com características indígenas.

Pode-se dizer que os índios de Fernando Pinto são uma releitura crítica do longo processo de exploração pelo qual passaram as terras e as tribos indígenas. O enredo de 1983, por exemplo, rendeu um samba que clamava pela manutenção das terras verdes e a preservação dos solos indígenas (Deixe nossa mata sempre verde / Deixe nosso índio ter seu chão), num veio político que permanece a gerar disputas judiciais de grande repercussão (vide os casos envolvendo a demarcação da reserva Raposa Serra do Sol e a construção da usina de Belo Monte). São índios carnavalizados que apontam para os riscos da aculturação e da marginalização social. O mesmo viés crítico é notável em "Tupinicópolis", enre- 
do que ao mostrar cenas cotidianas da metrópole indígena (do Cabaré da lara ao Shopping Boitatá) aponta, num contraste típico do carnaval, para a realidade que está além dos limites da Passarela do Samba: metrópoles em que os índios não são vistos, à exceção de alguns nomes de ruas e estátuas de bronze. De certa forma, o carnavalesco Renato Lage usou da mesma proposta crítica ao apresentar, na abertura do carnaval desenvolvido para a Mocidade Independente, em 2000, índios espaciais pendurados nas estruturas metálicas de uma imponente "navemãe", voltando do espaço sideral, para onde foram após séculos de violência. A interpretação carnavalesca da canção "Um índio", de Caetano Veloso, conseguiu manter o viés político bastante relevante da obra do compositor baiano.

Joãozinho Trinta e Rosa Magalhães são, certamente, os artistas que mais vezes fantasiaram brincantes de índios na era Sambódromo (pós-1984). Em linhas gerais, nos enredos de Joãozinho os índios figuram como nobres de "almas purificadas", seres de beleza física e espiritual (notar a semelhança com os índios românticos de Alencar) que habitavam nossas matas antes da presença branca, que transformaria o país em um inferno. ${ }^{16}$

Rosa Magalhães, por sua vez, reinventou a figura do índio ao longo dos seus carnavais, não ficando presa a um estereótipo. Se em 1994, na Imperatriz Leopoldinense, foi campeã a exaltar os índios belos e fortes que encantaram nobres europeus na festa ocorrida em Ruão em 1550 através do enredo "Catarina de Médicis na corte dos Tupinambôs e Tabajeres", declarou guerra, em 2002, ao "índio tocheiro de Catarina de Médicis", no enredo intitulado "Goitacazes: tupi or not tupi, in a south american way", que mostrava as mutações pelas quais a imagem do índio passou, em diferentes momentos da cena cultural brasileira, do romantismo de Alencar ao tropicalismo de Gil e Caetano. Os índios carnavalescos de Rosa, então, são mutantes, o que enriquece a análise da obra da artista e nos aproxima da produção literária que, contemporaneamente, procura dialogar com a temática indígena. Temos, hoje, um cenário literário que não mais retrata o indígena como um ser unilateral, mas complexo, na esteira das atuais reflexões antropológicas e das discussões sobre identidade e limites culturais. ${ }^{17}$

Ao final desse passeio por diferentes momentos do carnaval carioca, em cotejo com algumas obras literárias, notamos que as fantasias de índios continuam a colorir as folias da cidade. O Cacique de Ramos, bloco fundado em 1961, no bairro de Olaria, é o melhor exemplo disso (e uma análise um pouco mais cuidadosa das vestes tradicionais do bloco revela que o Cacique está mais para índio apache norte-americano que para selvagem brasileiro). Destacamos que o bloco não tem como símbolo um "índio de cordão" que foi duramente reprimido e passou por um processo de apagamento simbólico, no início do século XX, fato 
que seguramente contribuiu para a decadência dos cucumbis. Tal contexto deve ser investigado com exaustividade, mediante pesquisas iconográficas mais rigorosas e análises mais acuradas de textos jornalísticos da época. Mas isso é samba para outro desfile!

\section{REFERÊNCIAS BIBLIOGRÁFICAS}

ALENCAR, José de. O Guarani. São Paulo: Editora Ática, 2006.

ALMEIDA, Maria Cândida Ferreira de. Tornar-se outro. O topos canibal na literatura brasileira. São Paulo: Annablume, 1999.

ARAÚJO, Vânia Maria Mourão de. Yes, nós temos baianas: o processo de construção da personagem baiana de escola de samba no século XX. Dissertação (Mestrado), Instituto de Artes, Universidade do Estado do Rio de Janeiro, Rio de Janeiro, 2011.

BISCARDI, Afrânio. ROCHA, Frederico Almeida. O mecenato artístico de D. Pedro II e o Projeto Imperial. 19\&20, Rio de Janeiro, v. 1, n. 1, mai. 2006. Disponível em: <http://www.dezenovevinte.net/ensino_artistico/mecenato_dpedro.htm>.

CABRAL, Sérgio. As escolas de samba do Rio de Janeiro. São Paulo: Lazuli Editora/ Companhia Editora Nacional, 2011.

CANDIDO, Antonio. Formação da literatura brasileira. São Paulo: Martins, 1959.

CAVALCANTI, Maria Laura, GONÇALVES, Renata (orgs.). Carnaval em múltiplos planos. Rio de Janeiro: Aeroplano Editora, 2009.

CUNHA, Maria Clementina Pereira. Ecos da folia. Uma história social do carnaval carioca entre 1880 e 1920. São Paulo: Companhia das Letras, 2001.

DAMATTA, Roberto. Carnavais, malandros e heróis. Para uma sociologia do dilema brasileiro. Rio de Janeiro: Rocco, 1997.

EFEGÊ, Jota. Figuras e coisas do carnaval carioca. Rio de Janeiro: Funarte, 1982.

FERREIRA, Felipe. O livro de ouro do carnaval brasileiro. Rio de Janeiro: Ediouro, 2004.

. O marquês e o jegue: estudo da fantasia para escolas de samba. Rio de Janeiro: Altos da Glória, 1999.

GÓES, Fred. Entre reis e caciques no MardiGras de Nova Orleans. In: CAVALCANTI, Maria Laura, GONÇALVES, Renata (orgs.). Carnaval em múltiplos planos. Rio de Janeiro: Aeroplano Editora, 2009, p. 35-46.

LIRA NETO. O inimigo do rei: uma biografia de José de Alencar ou a mirabolante aventura de um romancista que colecionava desafetos, azucrinava D. Pedro II e acabou inventando o Brasil. Rio de Janeiro: Editora Globo, 2006.

MORAES, Eneida de. História do carnaval carioca. Rio de Janeiro: Civilização Brasileira, 1958.

MOREL, Marco. O mau selvagem: índios invisíveis no Romantismo brasileiro. In: LESSA, Mônica Leite; FONSECA, Silvia Carla Pereira de Brito. Entre a monar- 
quia e a república: imprensa, pensamento político e historiografia (1822 1889). Rio de Janeiro: Editora da Universidade do Estado do Rio de Janeiro, 2008.

PEREIRA, Aline Valadão Vieira Gualda. Os bate-bolas do carnaval carioca contemporâneo: dinâmicas e disputas simbólicas. In: CAVALCANTI, Maria Laura; GONÇALVES, Renata. (Orgs.). Carnaval em múltiplos planos. Rio de Janeiro: Aeroplano, 2009, p. 173-194.

. Tramas simbólicas: a dinâmica das turmas de bate-bolas do Rio de Janeiro. Dissertação (Mestrado) Instituto de Artes. Universidade do Estado do Rio de Janeiro, Rio de Janeiro, 2008.

. As turmas de bate-bolas do carnaval contemporâneo. Concinnitas, Rio de Janeiro, v. 2, p. 6-15, 2008a.

PEREIRA, Aline Valadão Vieira Gualda; FERREIRA, Felipe. Turmas de bate-bolas do carnaval contemporâneo do Rio de Janeiro: diversidade e dinâmica. Visualidades, Goiânia, v. 7, p. 45-68, 2009.

RIO, João do. A alma encantadora das ruas. São Paulo: Companhia das Letras, 2008.

SCHWARCZ, Lilia Moritz. As barbas do imperador. D. Pedro II, um monarca nos Trópicos. 2. ed. São Paulo: Companhia das Letras, 1999.

\section{NOTAS}

1 Samba de enredo defendido pela escola de samba Imperatriz Leopoldinense, no carnaval de 1994. Autores: Marcio André, Alvinho, Aranha e Alexandre da Imperatriz.

2 Samba de enredo defendido pela escola de samba Imperatriz Leopoldinense, no carnaval de 2002. Autores: Marquinhos Lessa, Guga e Tuninho Professor.

30 autor exemplifica a ideia mencionando fantasias de reis e duques (nobres em geral), caveiras e diabos (seres das sombras), gregos, romanos e chineses (povos distantes), ladrões, palhaços, prostitutas, caubóis e malandros ("figuras liminares que o cotidiano só revela dolorosamente"). A figura do índio pode ser enquadrada nessa última categoria. $O$ genocídio indígena pós1500 legou aos nativos brasileiros papel periférico, exótico, marginal em nossa sociedade.

4 Sobre as fantasias de clóvis, ou bate-bolas, ver Pereira, 2008, 2008a, 2009 e Pereira e Ferreira, 2009.

5 Expressão utilizada por Oswald de Andrade no Manifesto Antropófago, de 1928.

6 Marco Morel (2008, p. 125) afirma que durante o período do governo de dom João VI já apareciam algumas alegorias, iconografias e obras literárias de temática indígena, numa tentativa de diferenciar a identidade brasileira da matriz cultural europeia. 
7 Expressão utilizada por Antonio Candido (1959).

8 É curioso constatar que José de Alencar, maior expoente do romantismo indianista brasileiro, era um "inimigo do rei", uma vez que nunca escondeu a oposição a certas atitudes de Pedro II. O escritor, usando o pseudônimo Erasmo, publicou textos panfletários, condenando a corrupção que roía os tapetes do alto escalão. Além disso, criticou com veemência o poema épico $A$ Confederação dos Tamoios, de Gonçalves de Magalhães, feito sob encomenda do Imperador - que, adversário confesso, perseguia o romancista nas esferas da política. A ironia reside na percepção de que as obras regionalistas e indianistas de Alencar atendiam, sim, aos interesses do Império, unificados sob a égide do Instituto Histórico e Geográfico Brasileiro (LIRA NETO, 2006).

9 Sobre isso, aponta Maria Cândida Ferreira de Almeida (1999, p. 194): “O retorno ao passado, histórico ou mítico, era uma tentativa de ressignificar o presente e projetar o futuro, camuflando a violência e a destruição que marcaram o começo da colonização do Brasil".

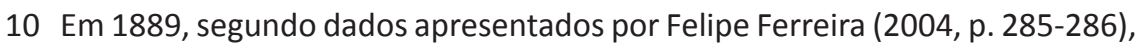
o Jornal do Commercio de 4 de março noticiou que a Sociedade Iniciadora dos Cucumbis Carnavalescos "desfilara apresentando dois estandartes, com seus sócios 'fantasiados de índios' e tocando 'instrumentos originais'. Em 1890, o mesmo periódico noticiou a passagem de dois grupos de cucumbis: "a Sociedade Iniciadora dos Cucumbis Africanos - e a sociedade dos Cucumbis Carnavalescos - trajando rico vestuário indígena".

11 Tanto Felipe Ferreira quanto Maria Clementina Pereira Cunha consideram 1932 um divisor de águas na história do carnaval carioca.

12 Ferreira (2004, p. 332) comenta que o periódico $O$ Jornal, de 30 de janeiro de 1932, "destacava que a comemoração se realizava em agradecimento ao fato de Pedro Ernesto ter tornado o Carnaval carioca oficial, ao auxílio destinado às Grandes Sociedades, ranchos e blocos, além da isenção de taxas e impostos sobre os primeiros festejos".

13 Sobre o surgimento e as modificações do conceito e do traje das baianas ver Araújo, 2011.

14 Vale lembrar que a "macumba", termo genérico utilizado para designar os cultos afro-brasileiros, intimamente relacionados às tias baianas, instigava a curiosidade da cena intelectual brasileira - e não à toa Macunaíma visita o terreiro de Tia Ciata, no capítulo intitulado "Macumba".

15 Dados colhidos do sítio www.galeriadosamba.com.br/V41/CA.asp?parm=\%3 $\mathrm{F} \% \mathrm{~F} 4 \% \mathrm{~F} 4 \% \mathrm{CA} \% \mathrm{E} 7 \% \mathrm{E} 754 \& \mathrm{BT}=\mathrm{OK}$.

16 Ver o enredo "Brasil: visões de paraísos e infernos", desenvolvido para a Unidos do Viradouro, no ano 2000; no qual os índios viviam em absoluta paz, antes do "achamento" do Brasil. A comunhão com a natureza, porém, seria pro- 
fundamente abalada com a presença do colonizador, que transformaria as vidas dos silvícolas em um inferno dantesco

17 Antonio Callado, em Quarup, obra de 1967, já levantava discussões sobre o processo de marginalização do indígena.

Leonardo Augusto Bora é licenciado em letras português-inglês (Pontifícia Universidade Católica do Paraná), bacharel em direito (Universidade Federal do Paraná) e mestrando (bolsista CNPq) em teoria literária (Universidade Federal do Rio de Janeiro).

Recebido em: 29/05/2012

Aceito em: 07/08/2012 